\title{
Inhibitory and facilitatory effects of microbial films on settlement of Balanus amphitrite amphitrite larvae
}

\author{
Sabine K. Wieczorek ${ }^{1}$, Anthony S. Clare ${ }^{2}$, Christopher D. Todd ${ }^{1}$ \\ ${ }^{1}$ Gatty Marine Laboratory, University of St. Andrews, St. Andrews, Fife KY16 8LB, United Kingdom \\ ${ }^{2}$ Marine Biological Association of the UK, The Laboratory, Citadel Hill, Plymouth PL1 2PB, United Kingdom
}

\begin{abstract}
Larvae of the barnacle Balanus amphitrite amphitrite Darwin (Crustacea: Cirripedia) respond to microbial surface film cues at settlement (i.e. attachment and metamorphosis). The effects of films of varying ages on the settlement behaviour of $B$. amphitrite cyprids were examined in laboratory choice assays using substrata preconditioned in natural seawater for longer periods (up to $18 \mathrm{~d}$ ) than previous studies. Furthermore, in this study only known numbers of cyprids (either 1 or 20 larvae) per film treatment were investigated, allowing assessment of possible behavioural interactions between larvae. Quantitative analyses of the multi-species films permitted objective comparisons between film age treatments. A general trend of a reversal of the effect of filming on cyprid settlement response - from inhibitory to facilitatory - was noted with increasing film age and isolated cyprids responded similarly to groups of 20 cyprids. Microbial abundance and overall biotic diversity were found to be markedly greater in 'older' films. The facilitation of cyprid settlement by 'older' films contrasts with previously published studies on $B$. amphitrite and may be explained either by the greater ages of films assayed in the present study or qualitative/quantitative differences in films between studies.
\end{abstract}

KEY WORDS: Settlement assays - Larval behaviour - Microbial films - Bacteria - Barnacles - Cyprids . Balanus a. amphitrite

\section{INTRODUCTION}

The importance of the use of microbial films as a settlement cue by the larvae of sessile marine macrofouling organisms has been well established for a wide range of invertebrate taxa (e.g. Raimondi 1988, Fitt et al. 1990, Johnson et al. 1991, Szewzyk et al. 1991, Holmström et al. 1992, Maki et al. 1992, Leitz \& Wagner 1993, Parsons et al. 1993, Neal \& Yule 1994a, b, Todd \& Keough 1994). Many previous, detailed analyses of the effects of microfouling on the settlement and metamorphosis of invertebrate larvae have focused primarily on overall physicochemical properties of microfilms, such as surface free energy (Eiben 1976 , Mihm et al. 1981, Kirchman et al. 1982, Maki \& Mitchell 1985, Maki et al. 1989, 1992, Roberts et al. 1991, Neal \& Yule 1994b). In the past little emphasis has been placed on the composition, growth phase or metabolic activity of the microbial film assemblages involved, and most studies generally considered only single species films (e.g. Neumann 1979, Weiner et al. 1985, Fitt et al. 1990, Szewzyk et al. 1991, Holmström et al. 1992, Leitz \& Wagner 1993, Neal \& Yule 1994a). Although single species studies enhance analytical tractability they cannot mimic the complexity of natural systems (Allison \& Gilbert 1992).

Kirchman et al. (1982) postulated that lectins produced by bacterial films may mediate the settlement of the polychaete Janua brasiliensis (see also Maki \& Mitchell 1985). With particular reference to the inhibition of barnacle settlement by microbial films, Maki et al. $(1990,1992)$ deduced that specific molecular components of bacterial extracellular polymers were more important than overall physical properties of the microfilms. Szewzyk et al. (1991) describe how exopolysaccharide polymers produced by bacteria for attachment could be altered by changing their growth conditions (see also Fletcher 1977, Fletcher \& Marshall 1982, Characklis 1981, Allison \& Gilbert 1992) and changes in the successional composition, physiological 
condition and growth phase of the microfilm community may well alter their effect on larval settlement (Neumann 1979) Some evidence has been presented that such changes are indeed of great importance in the cueing of invertebrate settlement. Thus, for example, larvae of the echinoid Strongylocentrotus droebachiensis prefer to settle onto 'older' (75 d) rather than 'young' (40 d) films of similar biomass (Pearce \& Scheibling 1991). For Balanus amphitrite, Maki et al. (1988, 1990, 1992) found that $4 \mathrm{~d}$ old cyprids were inhibited by 7 of the 18 bacterial species tested in their pure culture assays. They further noted age-related effects of films of the bacterium Deleya marina on the inhibition of attachment of the cyprids when compared to unfilmed polystyrene control dishes (see also Holmström et al. 1992): 'older' films were more inhibitory than were 'young' films. Inhibition of cyprid attachment has also been reported for natural multi-species microfilms on polystyrene petri dishes preconditioned in seawater (Maki et al. 1988, 1990, 1992), but those observations are confined to relatively young films, with substrata being preconditioned for only 24 to $120 \mathrm{~h}$. The use of varying, and often large, numbers of larvae in their assays (15 to 200 per dish, Maki et al. $1988,1990,1992)$ renders their data difficult to interpret in view of possible density-related behavioural effects. Yule \& Walker (1985) and Clare et al. (1994) have raised the possibility of cyprid-cyprid interactions at the time of settlement having important implications for the design of barnacle settlement assays, and the latter recommend utilization of low cyprid densities or even single larvae wherever possible.

Here we re-examine the effects of film age on the settlement response of Balanus amphitrite amphitrite cyprids to natural multi-species biofilms developed over longer preconditioning periods than in previous studies. We also report on settlement choice assays involving either a fixed, small number (20) of cyprids per dish, as recommended by Rittschof et al. (1992), or 1 larva per dish only (see Clare et al. 1994) to preclude any possible impact of larva-larva interactions. Comparative quantitative analyses of film composition were also carried out, in addition to assessments of bacterial growth activity, in order to more clearly define the film age parameter.

\section{MATERIALS AND METHODS}

Larvae. All cypris larvae of Balanus a. amphitrite were obtained from Duke University Marine Laboratory (Beaufort, North Carolina, USA), where they had been reared in batch culture from stage 1 nauplii on a diet of Skeletonema costatum (Greville) (CCMP 1332) as described by Rittschof et al. (1992). Larvae were stored in the dark at $6^{\circ} \mathrm{C}$ until used, and only 3 and $4 \mathrm{~d}$ old cyprids (Day $0=$ day of collection of newly transformed cyprids) were included in the settlement assays (Rittschof et al. 1984). For Expts 1 and 2 we used cyprids from separate single mass spawnings of a large number of adults.

Settlement assays. The water used in all settlement assays was $0.2 \mu \mathrm{m}$ filtered Eddystone seawater (FSW). For the initial assay (Expt 1, with 5 repeats denoted A to E) natural microbial films of different ages $(1,3,6,12$ and $18 \mathrm{~d}$ ) were obtained by submerging polystyrene petri dishes (Falcon 1006, $50 \times 9 \mathrm{~mm}$; basal area $19.6 \mathrm{~cm}^{2}$ ) in a roofed outdoor flow-through tank at the Citadel Hill Laboratory in Plymouth (UK) for the appropriate period of time. Water was pumped directly from Plymouth Hoe into the laboratory and entered the outdoor tank after being circulated through the laboratory's aquarium system. During the experimental period (April/May 1994) the water temperature in the tank was approximately $22^{\circ} \mathrm{C}$. Following filming, the dishes were emptied and any detritus was carefully washed off by dipping each dish 3 times in FSW. After filling the dishes with $5 \mathrm{ml}$ of FSW, 20 larvae (either 3 or $4 \mathrm{~d}$ old) were added to each. The control dishes (new, initially sterile, film age 0 , Fig. 1) were unconditioned and contained $5 \mathrm{ml}$ of FSW only. Cyprid settlement was counted after an incubation period of $24 \mathrm{~h}$ at room temperature $\left(-24^{\circ} \mathrm{C}\right)$. The terms 'inhibition' and 'facilitation' are applied here to those cases in which settlement was, respectively, significantly lower and higher than settlement for the (unfilmed) control. Larval 'settlement' as used in this study refers to permanent attachment (following expulsion of cement) of a cyprid.

Expt 2 concerned assays with single larvae (10 replicates of each treatment) in dishes with 4,8 and $12 \mathrm{~d}$ old films, but here the dishes were tilted during film conditioning by placing a support under one edge. Water from the flow-through tank was added until the meniscus had spread half way across the bottom of each dish (matching a prescored diagonal on the underside), so that one half (the 'left hand side') of each dish could be preconditioned whereas the other half remained untreated. The designation of the left hand side for the sterile control was arbitrary. Dishes were preconditioned in the dark and the conditioning water was changed daily until commencement of the experiments. For the assays, each dish was washed as above, placed horizontally and filled with $5 \mathrm{ml}$ of FSW. Controls were provided by (a) unconditioned (new, sterile) dishes and (b) dishes which had been half filled with only FSW for $12 \mathrm{~d}$. Orientation of dishes was randomized and, to preclude any light effects on settlement position, this experiment was run in the dark (at $28^{\circ} \mathrm{C}$ ); attached cyprids were counted after $26 \mathrm{~h}$. The 3 repeats of this experiment were all initiated within $24 \mathrm{~h}$ using larvae from the 
same batch; there was, therefore, the possibility of cyprid age effects among the repeats of this experiment which had to be allowed for in the analysis.

Analysis of microbial films. Following Repeat $E$ (Expt 1) all petri dishes from that experiment were preserved in formalin for acridine orange direct count epifluorescence analysis (AODC) (Parsons et al. 1984) and scanning electron microscopy (SEM) (JEOL JSM$35 \mathrm{CF}$ ) preparation. For AODC estimates, film bacteria for 4 of the replicates from each of the 1, 3,6, 12 and $18 \mathrm{~d}$ old film treatments were counted directly from subsamples of whole dish filtrations. For SEM, $1 \mathrm{~cm}$ discs were cut from 4 other replicate petri dishes with a heated metal cork borer; these were then dehydrated through an alcohol series, critical point dried in liquid $\mathrm{CO}_{2}$ and sputter coated with gold. The various categories of microorganisms (i.e. cocci, short rods, long rods, spirilla, vibrios, diatoms, protozoans) were then enumerated by counting 10 separate fields $\left(600 \mu \mathrm{m}^{2}\right)$ along 4 randomly selected diameter transects for each disc. Activity of the microbial films was determined from the SEM counts by the frequency of dividing cells method (Hagström et al. 1979).

Data analysis. Experiment 1: All percentage data were arc-sine transformed prior to analysis. The pooled data for all 5 repeats were compared using the GLM procedure in MINITAB (1991), with film age as the explanatory variable, number of attached cyprids as the response variable, and repeat number and cyprid age as the covariates. Since the probability values of both covariates were not significant at the $5 \%$ level, it was justifiable to analyze these as pooled data, but results for the separate repeats are also given. Analysis was by ANOVA, followed by Tukey's Multiple Comparisons for the factor film age.

Experiment 2: There was no significant interaction between the factor film age and either of the covariates cyprid age and repeat number $(\alpha=0.05$, GLM procedure; MINITAB 1991). Accordingly, the analysis was carried out for the pooled data from the 3 repeats using $\log$ likelihood ratio $G$-tests (with Williams' correction) for contingency tables (Zar 1984), followed by unplanned tests of the heterogeneity of replicates tested for goodness of fit (Sokal \& Rohlf 1981). The critical value for $G$ was $\chi_{0.05[4]}^{2}=9.488$. ANCOVA was carried out with the number of attached cyprids as the response variable, experiment repeat number as the explanatory variable and film age as the covariate.

Epifluorescence and SEM direct counts: Comparisons between film treatments of varying ages were undertaken for the total counts of diatoms, protozoans and bacteria $\mathrm{cm}^{-2}$, and for percentages of the dividing cell counts and the 7 individual film categories. Since the percentage data were not normally distributed, even after angular tranformation, the analysis was carried out by Kruskal-Wallis test, followed by Tukey-type Nonparametric Multiple Comparisons (Zar 1984). An overall general measure of film composition was obtained for the film age treatments with the Shannon-Wiener diversity index ( $H^{\prime}$, computed using $\log _{2}$ ) and the derivative measure of dominance, or evenness ( $J$, computed as $H^{\prime} / H_{\text {max }}^{\prime}$ ): these indices were obtained using the proportional abundances for the 7 components ( 5 bacterial types, diatoms, protozoans) enumerated.

\section{RESULTS}

\section{Experiment 1}

Fig. 1 includes separate histograms for Repeats A through $E$ of Expt 1, in addition to that for the entire pooled data set. For each of the 5 repeats, as well as the pooled data, the general pattern was one of inhibition by 1 and $3 \mathrm{~d}$ old films and facilitation by 12 or $18 \mathrm{~d}$ old films, but there were between-repeat variations in outcome (Fig. 1). Despite the clear overall effect of inhibition by both 1 and $3 \mathrm{~d}$ old films (Fig. 1, pooled data set), among the separate repeats it was only for $\mathrm{B}, \mathrm{C}$ and $\mathrm{E}$ that there was significantly less cyprid settlement than for the control on 1 and/or 3 d old films: of these only for Repeat $E$ did both 1 and 3 d old films give identical results. Similarly, it was only for Repeats D and E that there was significant facilitation by 'older' films; but in all repeats except $C$ there was significantly more cyprid settlement on 18 than $1 \mathrm{~d}$ old films.

\section{Experiment 2}

There were no significant between-repeat differences, thereby indicating that the unavoidable small differences in cyprid age ( $\leq 24 \mathrm{~h}$ ) had no effect on the outcome of the experiment. The results for the pooled data incorporating all 3 repeats for Expt 2 are given in Table 1. Cyprid settlement on the treatment ('left hand') side of experimental dishes bearing 'old' (12 d) films was significantly higher than the expectation of the null hypothesis (see Table 1). Conversely, settlement on the treatment side for 'young' (4 d) films was significantly less than the expected $50 \%$. The additive tests of heterogeneity did, however, show that although cyprid settlement was significantly different between the above 2 treatments, they were not heterogeneous from the observed numbers of cyprids attaching on the 'intermediate' ( $8 \mathrm{~d}$ ) films and for the controls. The overall outcome for this experiment thus complements that for Expt 1 in showing that 'young' films are unattractive to larvae ( $9 / 30$ on film) whereas 'old' films are very attractive (24/30 on film). Impor- 

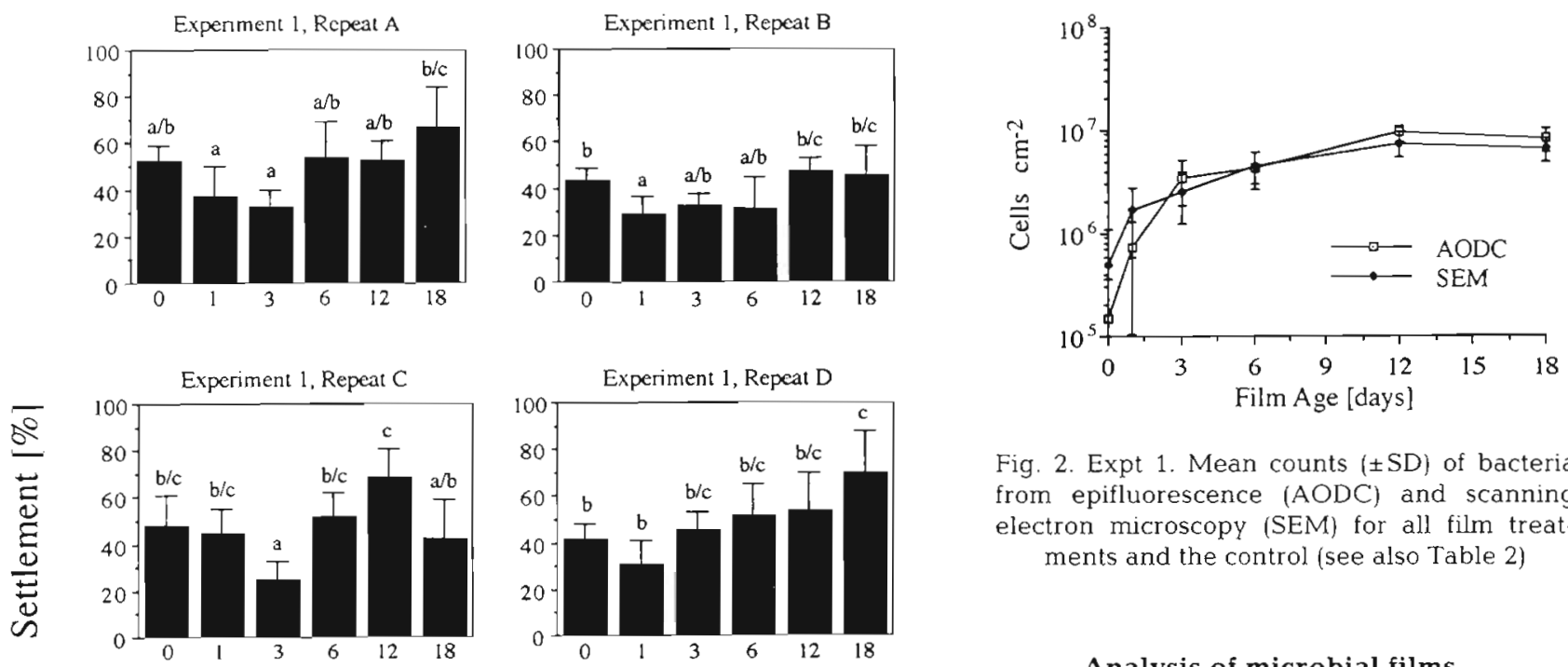

Fig. 2. Expt 1. Mean counts ( $\pm \mathrm{SD}$ ) of bacteria from epifluorescence (AODC) and scanning electron microscopy (SEM) for all film treatments and the control (see also Table 2)

\section{Analysis of microbial films}
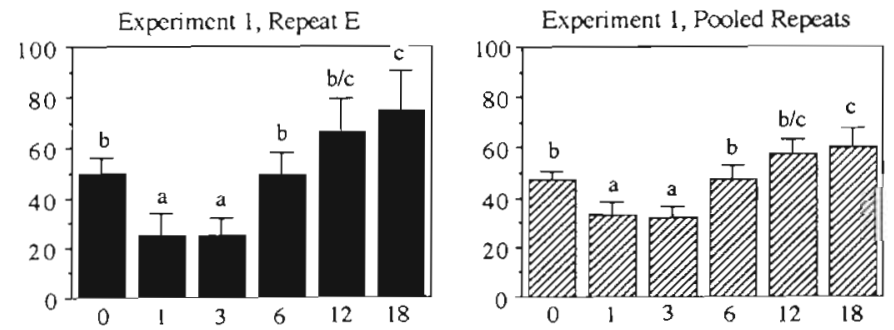

Total bacterial cell counts

Film Age [days]

Fig. 1. Balanus amphitrite amphitrite. Expt 1. Mean percentages of cyprid settlers ( $+95 \%$ confidence limits). a to c: ANOVA Tukey groups (a: percentage settlement significantly less than the film age 0 control; b: percentage settlement not significantly different from the control;

c: percentage settlement significantly greater than the control)

tantly, the outcomes of these 2 sets of experiments also indicate that there are no behavioural differences in responses to films for isolated individuals versus groups of 20 larvae. interest is the observation that the 12 and $18 \mathrm{~d}$ counts were not significantly different from one another, indicating that although cells were still dividing some must be lost in some way. It is possible that after reaching a certain bacterial density these micro-

Table 1. Balanus amphitrite amphitrite. Expt 2. Unplanned tests of heterogeneity of replicates tested for goodness of fit. Observed frequency distributions of cyprid settlers (given in descending order) are considered heterogeneous for additive tests with $\mathrm{p} \leq$ 0.05. Critical value for $G=\chi^{2} 0_{05(4)}=9.488, H_{0}=50.50$ distribution; critical value for $G=\chi_{0.01 i 4 \mid}^{2}=13.277, H_{0}=50.50$ distribution. n: number of replicates; FSW: $0.2 \mu \mathrm{m}$ filtered seawater; $G_{\text {adj }}: G$ adjusted by Williams' correction

\begin{tabular}{|c|c|c|c|c|c|c|}
\hline \multirow[t]{3}{*}{ Experimental substratum } & \multirow{2}{*}{\multicolumn{2}{|c|}{$\begin{array}{l}\text { Frequency of settlers } \\
\text { on treatment side }\end{array}$}} & \multirow[t]{3}{*}{$\mathrm{n}$} & \multicolumn{2}{|c|}{$G_{\text {adj }}$ for additive tests of heterogeneity } & \multirow[t]{3}{*}{$\mathrm{p}$} \\
\hline & & & & \multirow{2}{*}{$\begin{array}{l}\text { Highest observed } \\
\text { frequencies first }\end{array}$} & \multirow{2}{*}{$\begin{array}{l}\text { Lowest observed } \\
\text { frequencies first }\end{array}$} & \\
\hline & Observed & Expected & & & & \\
\hline 12 d old film & 24 & 15 & 30 & & 15.711 & $<0.01$ \\
\hline Sterile (control) & 19 & 15 & 30 & 1.957 & 7.292 & $>0.05$ \\
\hline $12 \mathrm{~d}$ exposure to FSW (control) & 17 & 15 & 30 & 3.834 & 4.909 & $>0.05$ \\
\hline $8 \mathrm{~d}$ old film & 16 & 15 & 30 & 5.430 & 3.204 & $>0.05$ \\
\hline $4 \mathrm{~d}$ old film & 9 & 15 & 30 & 15.713 & & $<0.01$ \\
\hline
\end{tabular}


Table 2. Expt 1 Mean counts $\mathrm{cm}^{-2}$ (SE) of total bacterial cells, diatoms and protozoans for all film treatments and the control obtained by Acridine Orange direct counts (AODC: 4 replicates, 20 counts per treatment) and scanning electron microscopy counts (SEM: 4 replicates, 40 counts per treatment). Initial analysis done by Kruskal-Wallis tests (p) followed by Tukey-type analysis. a to e: homogeneous $(\alpha=0.05)$ groups from the Tukey-type analysis (n: number of observations)

\begin{tabular}{|c|c|c|c|c|c|c|}
\hline \multirow[t]{2}{*}{ Film age (d) } & \multicolumn{2}{|r|}{ AODC } & \multicolumn{4}{|c|}{ SEM } \\
\hline & $n$ & Total bacteria & $\mathrm{n}$ & Total bacteria & Diatoms & Protozoans \\
\hline 0 & 80 & $\begin{array}{l}1.5 \times 10^{5} \mathrm{a} \\
\left(2.3 \times 10^{4}\right)\end{array}$ & 160 & $\begin{array}{l}4.9 \times 10^{5} \mathrm{a} \\
\left(4.7 \times 10^{4}\right)\end{array}$ & $\begin{array}{l}1.0 \times 10^{3} \mathrm{a} \\
\left(1.0 \times 10^{3}\right)\end{array}$ & $\begin{array}{l}0.0 \mathrm{a} \\
(0.0)\end{array}$ \\
\hline 1 & 80 & $\begin{array}{l}7.2 \times 10^{5} \mathrm{~b} \\
\left(6.9 \times 10^{4}\right)\end{array}$ & 160 & $\begin{array}{l}1.7 \times 10^{6} \mathrm{~b} \\
\left(8.8 \times 10^{4}\right)\end{array}$ & $\begin{array}{l}4.2 \times 10^{3} \mathrm{a} \\
\left(2.1 \times 10^{3}\right)\end{array}$ & $\begin{array}{l}3.1 \times 10^{3} \mathrm{a} / \mathrm{b} \\
\left(1.8 \times 10^{3}\right)\end{array}$ \\
\hline 3 & 80 & $\begin{array}{l}3.5 \times 10^{6} \mathrm{c} \\
\left(1.8 \times 10^{5}\right)\end{array}$ & 160 & $\begin{array}{l}2.6 \times 10^{6} \mathrm{C} \\
\left(1.0 \times 10^{5}\right)\end{array}$ & $\begin{array}{l}6.3 \times 10^{3} \mathrm{a} \\
\left(2.9 \times 10^{3}\right)\end{array}$ & $\begin{array}{l}1.0 \times 10^{4} \mathrm{a} / \mathrm{b} \\
\left(3.5 \times 10^{3}\right)\end{array}$ \\
\hline 6 & 80 & $\begin{array}{l}4.3 \times 10^{6} \mathrm{c} \\
\left(1.9 \times 10^{5}\right)\end{array}$ & 160 & $\begin{array}{l}4.5 \times 10^{6} \mathrm{~d} \\
\left(1.2 \times 10^{5}\right)\end{array}$ & $\begin{array}{l}1.1 \times 10^{4} \mathrm{a} \\
\left(3.7 \times 10^{3}\right)\end{array}$ & $\begin{array}{l}1.9 \times 10^{4} \mathrm{a} / \mathrm{b} / \mathrm{c} \\
\left(5.1 \times 10^{3}\right)\end{array}$ \\
\hline 12 & 80 & $\begin{array}{l}9.4 \times 10^{6} \mathrm{~d} \\
\left(1.8 \times 10^{5}\right)\end{array}$ & 160 & $\begin{array}{l}7.4 \times 10^{6} \mathrm{e} \\
\left(1.6 \times 10^{5}\right)\end{array}$ & $\begin{array}{l}2.7 \times 10^{4} \mathrm{a} \\
\left(5.7 \times 10^{3}\right)\end{array}$ & $\begin{array}{l}6.1 \times 10^{4} \mathrm{c} \\
\left(8.9 \times 10^{3}\right)\end{array}$ \\
\hline 18 & 80 & $\begin{array}{l}8.2 \times 10^{6} \mathrm{~d} \\
\left(2.3 \times 10^{5}\right)\end{array}$ & 160 & $\begin{array}{l}6.7 \times 10^{6} \mathrm{e} \\
\left(1.4 \times 10^{5}\right)\end{array}$ & $\begin{array}{l}1.9 \times 10^{4} \mathrm{a} \\
\left(4.7 \times 10^{3}\right)\end{array}$ & $\begin{array}{l}3.9 \times 10^{4} \mathrm{~b} / \mathrm{c} \\
\left(7.0 \times 10^{3}\right)\end{array}$ \\
\hline $\mathrm{p}$ & & $<0.001$ & & $<0.001$ & 0.302 & $<0.001$ \\
\hline
\end{tabular}

films on polished plastic substrata undergo sloughing (Rittmann 1989, Allison \& Gilbert 1992), either as a natural process or perhaps as a result of the preparatory rinsing of the dish. The increasing numbers of protozoans for the older film treatments also may be implicated in reducing those bacterial numbers.

Film activity

The estimate by SEM direct counting of the frequency of bacterial cell division showed an apparent trend of decreasing activity over the investigated age range (Table 3), as indicated by the 2 overlapping Tukey groups (Fig 3).

\section{Diatoms}

Diatom counts $\mathrm{cm}^{-2}$ were low (Table 2) and although numbers apparently increased with film age, there was no significant between-treatment difference $(\mathrm{p}=$ $0.302)$.

\section{Protozoans}

Protozoans were absent from $0 \mathrm{~d}$ controls but, where present on other biofilms, were predominantly attributable to an Acanthoeca-like colonial choanoflagellate. The numbers of protozoans $\mathrm{cm}^{-2}$ varied between treatments but generally increased with film age (Table 2).

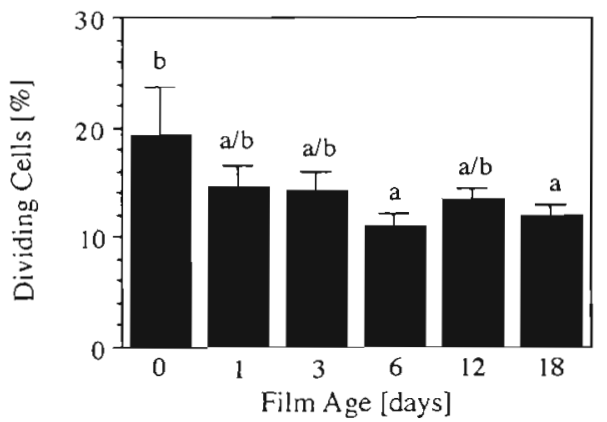

Fig. 3. Expt 1. Mean percentages of dividing cell counts $(+95 \%$ confidence limits) for all film treatments and the control. a, b as in Fig. 1

\section{Bacterial film composition and overall diversity}

With the exception of spirilla $(p=0.122)$, all recognized bacterial categories showed significant agerelated changes (Table 3 ). Short rods dominated the film composition throughout, but their average proportion declined significantly with film age and was inversely related to the relative abundances of other categories (Fig. 4). The overall pattern of a general increase in complexity of the biofilms (bacteria, diatoms and protozoans) with time is reflected by both the diversity and evenness values in Fig. 4.

\section{DISCUSSION}

Maki et al. $(1990,1992)$ showed that components of the bacterial extracellular polymers are involved in 
Table 3. Expt 1. Mean percentages (SE) of dividing cells and recognized bacterial components of all film treatments obtained by scanning electron microscopy counts (SEM). Initial analysis done by Kruskal-Wallis tests (p) followed by Tukey-type analysis. a to $c$ : homogeneous $(\alpha=0.05)$ groups from the Tukey-type analysis ( $n=$ number of observations)

\begin{tabular}{|c|c|c|c|c|c|c|c|}
\hline Film age $(\mathrm{d})$ & $\mathrm{n}$ & Dividing cells & Short rods & Long rods & Spirilla & Vibrios & Cocci \\
\hline 0 & 160 & $\begin{array}{l}19.5 b \\
(3.9)\end{array}$ & $\begin{array}{l}81.7 \mathrm{C} \\
(2.8)\end{array}$ & $\begin{array}{l}2.1 \mathrm{a} \\
(1.0)\end{array}$ & $\begin{array}{c}0.8 \mathrm{a} \\
(0.5)\end{array}$ & $\begin{array}{l}6.9 \mathrm{a} \\
(2.0)\end{array}$ & $\begin{array}{l}9.0 \mathrm{a} \\
(2.0)\end{array}$ \\
\hline 1 & 160 & $\begin{array}{l}13.4 \mathrm{a} / \mathrm{b} \\
(1.0)\end{array}$ & $\begin{array}{l}81.5 \mathrm{c} \\
(1.7)\end{array}$ & $\begin{array}{l}1.1 \mathrm{a} \\
(0.3)\end{array}$ & $\begin{array}{l}1.1 \mathrm{a} \\
(0.3)\end{array}$ & $\begin{array}{l}6.3 \mathrm{a} \\
(0.8)\end{array}$ & $\begin{array}{l}9.2 \mathrm{a} / \mathrm{b} \\
(1.2)\end{array}$ \\
\hline 3 & 160 & $\begin{array}{l}13.9 \mathrm{a} / \mathrm{b} \\
(0.8)\end{array}$ & $\begin{array}{l}71.3 b \\
(1.8)\end{array}$ & $\begin{array}{l}2.9 \mathrm{a} / \mathrm{b} \\
(0.5)\end{array}$ & $\begin{array}{l}0.9 \mathrm{a} \\
(0.2)\end{array}$ & $\begin{array}{l}12.8 \mathrm{~b} \\
(1.3)\end{array}$ & $\begin{array}{l}12.3 \mathrm{~b} / \mathrm{c} \\
(1.2)\end{array}$ \\
\hline 6 & 160 & $\begin{array}{l}10.8 \mathrm{a} \\
(0.6)\end{array}$ & $\begin{array}{l}74.2 \mathrm{~b} / \mathrm{c} \\
(1.2)\end{array}$ & $\begin{array}{l}4.9 \mathrm{~b} \\
(0.5)\end{array}$ & $\begin{array}{l}0.7 \mathrm{a} \\
(0.2)\end{array}$ & $\begin{array}{l}10.9 \mathrm{~b} \\
(0.6]\end{array}$ & $\begin{array}{l}9.0 \mathrm{a} / \mathrm{b} / \mathrm{c} \\
(0.6)\end{array}$ \\
\hline 12 & 160 & $\begin{array}{l}12.9 \mathrm{a} / \mathrm{b} \\
(0.5)\end{array}$ & $\begin{array}{l}63.2 \mathrm{a} \\
(1.3)\end{array}$ & $\begin{array}{l}10.7 \mathrm{C} \\
(0.7)\end{array}$ & $\begin{array}{l}1.1 \mathrm{a} \\
(0.2)\end{array}$ & $\begin{array}{l}12.3 b \\
(0.5)\end{array}$ & $\begin{array}{l}12.7 \mathrm{c} \\
(0.6)\end{array}$ \\
\hline 18 & 160 & $\begin{array}{l}11.2 a \\
(0.5)\end{array}$ & $\begin{array}{l}61.9 \mathrm{a} \\
(1.2)\end{array}$ & $\begin{array}{l}9.6 \mathrm{c} \\
(0.6)\end{array}$ & $\begin{array}{l}0.9 \mathrm{a} \\
(0.2)\end{array}$ & $\begin{array}{l}14.6 \mathrm{~b} \\
(0.6)\end{array}$ & $\begin{array}{l}13.1 \mathrm{c} \\
(0.6)\end{array}$ \\
\hline $\mathrm{p}$ & & 0.001 & $<0.001$ & $<0.001$ & 0.122 & $<0.001$ & $<0.001$ \\
\hline
\end{tabular}

determining barnacle cyprid electivity and our data show clearly that the effect of a natural microfilm on the settlement response of Balanus a. amphitrite amphitrite larvae in the laboratory can change from inhibitory (less than unfilmed control) to facilitatory (greater than unfilmed control) as the film ages. It is intuitive that larvae of intertidal invertebrates such as barnacles might, therefore, be able to obtain indirect information about the tidal height of a given substratum from components of surface microfilms alone. An apparently adaptive response was shown by Strathmann et al. (1981) from field experiments on the barnacles Balanus glandula and Semibalanus (= Balanus)
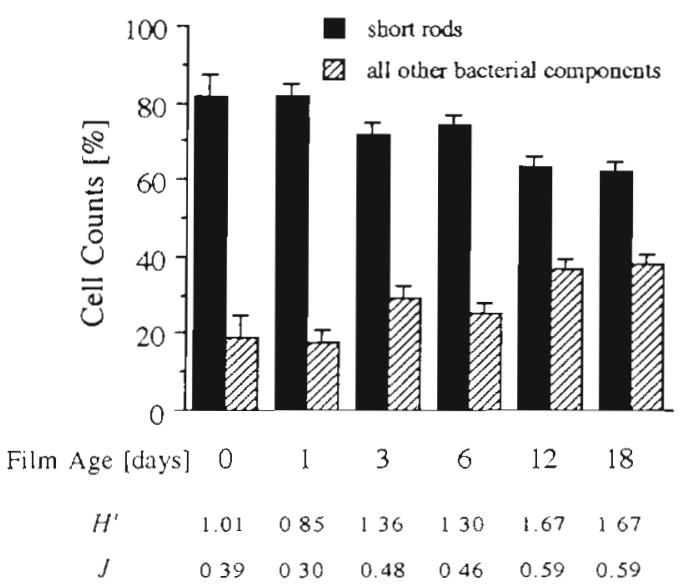

Fig. 4. Expt 1. Mean percentages of bactenal cell counts for short rods and the pooled remaining 4 bacterial film components ( $+95 \%$ confidence limits) for all film treatments and the control. Overall diversity ( $H^{\prime}$, Shannon-Wiener index) and evenness $(J)$ computed for all 7 microbial components enumerated are included also cariosus. Those species seem able to utilize microfilms to identify their optimal tidal height for settlement on the shore (but see also Grosberg 1982). Our analysis of microfilms of different ages showed an increase in bacterial density and overall microbial diversity, as well as a change in metabolic activity; these shifts in film composition and physiological state are reflected in significant changes in the 'attractiveness' of films to settling cyprids of B.a. amphitrite. Because numbers of microalgae were very low, and did not vary significantly between film age treatments, it seems unlikely that they are implicated in overall attractiveness of films to the larvae, although they might still to some extent affect larval behaviour at settlement. That previous investigators (Maki et al. 1988, 1990, 1992, Holmström et al. 1992, Avelin Mary et al. 1993) also found $B$. amphitrite larvae to respond to bacterial films, supports the suggestion that bacteria rather than microalgae are used as a settlement cue.

Avelin Mary et al. (1993) tested the effects of films of individual bacterial strains isolated from natural biofilms associated with the adult barnacles on Balanus amphitrite settlement. They found that all Vibrio films and most other isolates were inhibitory and no film facilitated cyprid settlement; this is in contrast to the present study, in which 'older' films (comprising larger proportions of the shape category 'vibrios') clearly facilitated settlement. Maki et al. $(1988,1990,1992)$ also reported the majority of their monoculture films to be either inhibitory or to have no effect on the behaviour of $B$ amphitrite larvae at settlement. However, Maki et al. (1990) did show facilitation of B. amphitrite settlement on polystyrene petri dishes bearing $1 \mathrm{~d}$ old natural multi-species biofilms in comparison to unfilmed control dishes. Moreover, they found signifj- 
cantly fewer attached cyprids on dishes with $3 \mathrm{~d}$ old films. They concluded that the predominant effect both of individual bacterial species and natural multispecies films on $B$. amphitrite settlement is inhibitory. Those results ascribing inhibitory effects of microbial films are not necessarily contradictory to our findings, since facilitation was noted only for our 'older' (12 and 18 d) films. Significant temporal changes in film effects on the attraction of larvae to a substratum are not unusual. For example, a recent study on Elminius modestus by Neal \& Yule (1994a) showed that the production of stimulatory and inhibitory factors within the biofilm is dependent upon biofilm age and is manifested by a reversal in cyprid responses to Deleya marina films. Those larvae which had temporarily attached to a film-bearing surface adhered more strongly to $4 \mathrm{~d}$ old films than to unfilmed surfaces, but less strongly to 1 mo old films.

Results of settlement assays for invertebrate larvae are often difficult to replicate, even when the same species and an identical methodology are used (see Raimondi \& Keough 1990 for review of variation in larval behaviour). Irrespective of the inevitable betweenbatch variation in larval responses, experimental variation is perhaps compounded when different ages or numbers and densities of larvae are utilized by different investigators. This we have attempted to assess by undertaking assays both with groups of 20 larvae and isolated individuals. Previous work specifically on Balanus amphitrite settlement (Maki et al. 1988, 1990, 1992) has shown that cyprid age and batch of larvae do indeed affect larval settlement behaviour (e.g. Holm 1990), but in a quantitative rather than qualitative way: cyprids become less discriminating with age, but still display the same response in settlement assays (Rittschof et al. 1984, Mitchell \& Maki 1988). In the present study only larvae from single batches were utilized in the 2 experiments, and cyprid age was restricted to 3 and $4 \mathrm{~d}$ old larvae; moreover, isolated larvae responded similarly to groups of 20 larvae at 4 larvae $\mathrm{ml}^{-1}$; approximately 1 larva $\mathrm{cm}^{-2}$ of basal dish area), indicating that there were no density-related changes in larval behaviour, at least at that larval concentration. With specific reference to barnacle cyprids it is likely that cueing of larval settlement by microbial surface films is a highly complex process, in which even slight local, seasonal and short-term temporal changes in film composition, density and physiology play an important role. Such is apparent from the present results which show significant changes from inhibition to facilitation as the films age.

Acknowledgements. We thank the Marine Laboratory of the Duke University at Beaufort, North Carolina, for supplying us with barnacle cyprids. Special thanks go to Irvine Davidson for technical assistance with the SEM. We also gratefully acknowledge the support of this work by the Marine Biological Association of the UK.

\section{LITERATURE CITED}

Allison, D. G., Gilbert, P. (1992). Bacterial biofilms. Sci. Progress 76: 305-321

Avelin Mary (Sr), Vitalina Mary (Sr), Rittschof, D., Nagabhushanan, R. (1993). Bacterial-barnacle interaction: potential of using juncellins and antibiotics to alter structure of bacterial communities. J. chem. Ecol. 19: 2155-2167

Clare, A. S., Freet, R. K., McClary, M. (1994). On the antennular secretion of the cyprid of Balanus amphitrite, and its role as a settlement pheromone. J. mar. biol Ass. U.K. 74:243-250

Characklis, W. G. (1981). Microbial fouling: a process analysis. In: Somerscales, E. F. C., Knudsen, J. G. (eds.) Fouling of heat transfer equipment. Hemisphere Publ. Co., London, p. 251-291

Eiben, R. (1976). Einfluss von Benetzungsspannung und Ionen auf die Substratbesiedlung und das Einsetzen der Metamorphose bei Bryozoenlarven (Bowerbankia gracilis). Mar. Biol. 37: 249-254

Fitt, W. K., Coon, S. L., Walch, M., Weiner, R. M., Colwell, R. R., Bonar, D. B. (1990). Settlement behaviour and metamorphosis of oyster larvae (Crassostrea gigas) in response to bacterial supernatants. Mar. Biol. 106: 389-394

Fletcher, M. (1977). The effects of culture age, time, and temperature on bacterial attachment to polystyrene. Can. J. Microbiol. 23: 1-6

Fletcher, M., Marshall, K. C. (1982). Are solid surfaces of ecological significance to aquatic bacteria? Adv. microb. Ecol. 6: $199-236$

Grosberg, R. K. (1982). Intertidal zonation of barnacles: the influence of planktonic zonation of larvae and vertical distribution of adults. Ecology 63: 894-899

Hagström, A., Larsson, U., Horstedt, P., Normark, S. (1979). Frequency of dividing cells, a new approach to the determination of bacterial growth rates in aquatic environments. Appl. environ. Microbiol. 37: 805--812

Holm, E. R. (1990). Attachment behavior in the barnacle Balanus amphitrite amphitrite (Darwin): genetic and environmental effects. J. exp. mar. Biol. Ecol. 135: 85-98

Holmström, C., Rittschof, D., Kjelleberg, S. (1992). Inhibition of settlement by larvae of Balanus amphitrite and Ciona intestinalis by a surface-colonizing marine bacterium. Appl. environ. Microbiol. 58: 2111-2115

Johnson, C. R., Muir, D. G., Reysenbach, A. L. (1991). Characteristic bacteria associated with surfaces of coralline algae: a hypothesis for bacterial induction of marine invertebrate larvae. Mar. Ecol. Prog. Ser. 74: 281-294

Kirchman, D., Graham, S., Reish, D., Mitchell, R. (1982). Lectins may mediate in the settlement and metamorphosis of Janua (Dexiospira) brasiliensis Grube (Polychaeta: Spirorbidae). Mar. Biol. Lett. 3: 131-142

Leitz, T., Wagner, T (1993). The marine bacterium Alteromonas espejiana induces metamorphosis of the hydroid Hydractinia echinata. Mar. Biol 115: 173-178

Maki, J. S., Mitchell, R. (1985). Involvement of lectins in the settlement and metamorphosis of marine invertebrate larvae. Bull. mar. Sci. 37: 675-683

Maki, J. S., Rittschof, D., Costlow, J. D., Mitchell, R. (1988). Inhibition of attachment of larval barnacles, Balanus amphitrite, by bacterial surface films. Mar. Biol. 97 : $199-206$ 
Makı, J. S., Rittschof, D., Mitchell, R. (1992). Inhibition of larval barnacle attachment to bacterial films: an investigation of physical properties. Microb. Ecol. 23: 97-106

Maki, J. S., Rittschof, D., Samuelsson, M.-O., Szewzyk, U. Yule, A. B., Kjelleberg, S., Costlow, J. D., Mitchell, R. (1990). Effect of marine bacteria and their exopolymers on the attachment of barnacle cypris larvae. Bull. mar. Sci. 46 . $499-511$

Maki, J S., Rittschof, D., Schmidt, A. R., Snyder, A. G., Mitchell, R. (1989). Factors controlling attachment of bryozoan larvae: a comparison of bacterial films and unfilmed surfaces. Biol. Bull. 177: 295-302

Mihm, J. W., Banta, W. C., Loeb, G. I. (1981). Effects of adsorbed organic and primary fouling films on bryozoan settlement. J. exp. mar. Biol. Ecol. 54: 167-179

MINITAB (1991). Minitab user's manual, version 8.2 edn. Minitab, Inc., State College, PA

Mitchell, R., Maki, J. S. (1988). Microbial surface films and their influence on larval settlement and metamorphosis in the marine environment. In: Thompson, M.-F., Sarojini, R., Nagabhushanam, R. (eds.) Marine biodeterioration: advanced techniques applicable to the Indian Ocean. Oxford \& IBH Publishing Co., New Delhi

Neal, A. L., Yule, A. B. (1994a). The interaction between Elminius modestus Darwin cyprids and biofilms of Deleya marina NCMB1877. J. exp. mar Biol. Ecol. 176: 123-139

Neal, A. L., Yule, A. B. (1994b). The tenacity of Eminius modestus and Balanus perforatus cyprids to bacterial films grown under different shear regimes. J mar. biol. Ass. U.K. 74: 251-257

Neumann, R. (1979). Bacterial induction of settlement and metamorphosis in the planula larvae of Cassiopea andromeda (Cnidaria: Scyphozoa, Rhizostomeae). Mar. Ecol. Prog. Ser. 1: 21-28

Parsons, G. J., Dadswell, M. J., Roff, J. C. (1993). Influence of biofilm on settlement of sea scallop, Placopecten magellanicus (Gmelin, 1791), in Passamaquoddy Bay, New Brunswick, Canada. J. Shellfish Res. 12: 279-283

Parsons, T R., Maita, Y., Lalli, C. M. (1984). Manual of chemıcal and biological methods for seawater analysis. Pergamon Press, New York

Pearce, C. M. Scheibling, R. E. (1991). Effect of macroalgae, microbial films, and conspecifics on the induction of metamorphosis of the green sed urchin, Strongylocentrotus droebachiensis (Müller). J. exp. mar. Biol. Ecol. 147: 147-162

This article was submitted to the editor
Raimondi, P. T. (1988). Settlement cues and determination of the vertical limit of an intertidal barnacle. Ecology 69: $400-407$

Raimondi, P. T., Keough, M. J. (1990). Behavioural variability in marine larvae. Aust. J. Ecol. 15: 427-437

Rittmann, B. E. (1989). Detachment of biofilms. In: Characklis, W. G., Wilderer, P. A. (eds.) Structure and function of biofilms. John Wiley \& Sons Lid, New York

Rittschof, D., Branscomb, E. S., Costlow, J. D. (1984). Settlement and behaviour in relation to flow and surface in larval barnacles, Balanus amphitrite Darwin. J exp. mar Biol. Ecol. 82: 131-146

Rittschof, D., Clare, A. S., Gerhart, D. J., Avelin Mary (Sr), Bonaventura, J. (1992). Barnacle in vitro assays for biologically active substances: toxicity and settlement inhibition assays using mass cultured Balanus amphitrite amphitrite Darwin. Biofouling 6: 115-122

Roberts, D., Rittschof, D., Holm, E., Schmidt, A. R. (1991). Factors influencing initial larval settlement: temporal, spatial and surface molecular components. J. exp. mar. Biol. Ecol. 150: $203-221$

Sokal, R. R., Rohlf, J F. (1981). Biometry: the principles and practice of statistics in biological research. W. H. Freeman, New York

Strathmann, R. R., Branscomb, E. S., Vedder, K. (1981) Fatal errors in set as a cost of dispersal and the influence of intertidal flora on set of barnacles. Oecologia 48: $13-18$

Szewzyk, U., Holmström, C., Wrangstadh, M., Samuelsson, M.-O., Maki, J. S., Kjelleberg, S. (1991). Relevance of exopolysaccharide of marine Pseudomonas sp. strain S9 for the attachment of Ciond intestinalis larvae. Mar. Ecol. Prog. Ser. 75: 259-265

Todd, C. D., Keough, M. J. (1994). Larval settlement in hard substratum epifaunal communities: a manipulative field study of the effects of substratum filming and the presence of incumbents. J. exp. mar. Biol. Ecol. 181: 159-187

Weiner, R. M., Segall, A. M., Colwell, R. R. (1985). Characterization of a marine bacterium associated with Crassostrea virginica (the eastern oyster). Appl. environ. Microbiol. 49 $83-90$

Yule, A. B, Walker, G. (1985). Settlement of Balanus balanoides: the effect of cyprid antennular secretion. J. mar biol. Ass. U.K. 65: 707-712

Zar, J. H. (1984). Biostatistical analysis. Prentice-Hall, Englewood Cliffs, NJ

Manuscnpt first received: September 4, 1994

Revised version accepted: December 20, 1994 